\title{
Sin, Confession, and the Arts of Book- and Cord- Keeping: An Intercontinental and Transcultural Exploration of Accounting and Governmentality
}

\section{Citation}

Urton, Gary. 2009. Sin, confession, and the arts of book- and cord-keeping: An intercontinental and transcultural exploration of accounting and governmentality. Comparative Studies in Society and History 51(4): 801-831.

\section{Published Version}

doi:10.1017/S0010417509990144

\section{Permanent link}

http://nrs.harvard.edu/urn-3:HUL.InstRepos:3716616

\section{Terms of Use}

This article was downloaded from Harvard University's DASH repository, and is made available under the terms and conditions applicable to Other Posted Material, as set forth at http:// nrs.harvard.edu/urn-3:HUL.InstRepos:dash.current.terms-of-use\#LAA

\section{Share Your Story}

The Harvard community has made this article openly available.

Please share how this access benefits you. Submit a story.

\section{Accessibility}




\title{
Sin, Confession, and the Arts of Book- and Cord-Keeping: An Intercontinental and Transcultural Exploration of Accounting and Governmentality
}

\author{
GARY URTON \\ Harvard University
}

\section{IN TR O DUCTION}

My objective is to examine an intriguing and heretofore unrecognized convergence in the history of bookkeeping. The story revolves around an extraordinary parallelism in the evolution of bookkeeping and the philosophical and ethical principles underlying the practice of accounting between southern Europe and Andean South America during the two centuries or so prior to the Spanish invasion of the Inka Empire in 1532. The event of the European invasion of the Andes brought these two similar yet distinct trans-Atlantic traditions of "bookkeeping" and accounting into violent confrontation.

At least two centuries before conquistador Francisco Pizarro set foot on the shores of what is today Peru, accountants in both southern Europe and the Andes had developed highly sophisticated methods of accounting and record keeping based on checks and balances using decimal place systems of numeration. The claim that I make and argue for here is that both accounting traditions emerged in intimate, interactive association with beliefs and practices associated with what are termed in English "sin" and "confession." That is, in both the Old and New Worlds, accounting and bookkeeping or record keeping developed at least partially in relation to practices of maintaining precise records of personal transgressive actions - behaviors that people in the two radically different societies considered as threatening to the fabric and well being of society. In Spain, these behaviors and actions were called

Acknowledgments: Thanks to the following individuals for reading and commenting on earlier versions of this paper: James Aho, Carrie Brezine, Alan Durston, and Adriana von Hagen. I was fortunate to receive extremely helpful comments, criticisms, and suggestions from four anonymous readers for $C S S H$. I am deeply grateful to all who read and commented on my initial attempts to formulate the arguments that have finally taken shape in the present paper. I alone am responsible for the arguments, and any errors of content, logic, or judgment herein. 
pecado; in the Andes, the Quechua term was hucha. Hand in hand with the practice of keeping accounts of disorderly, "sinful" behavior, there emerged in both the southern European and Andean accounting traditions elaborate procedures for restitution, or the redress of transgressive behavior, in the form of public and private confessions.

Increasingly sophisticated accounting and control procedures in southern Europe developed in close relationship with private financial accounting in wealthy mercantile capitalist houses, while the Andean procedures developed in intimate relation with state administrative controls and what is commonly termed governmentality. Between the thirteenth and fourteenth centuries C.E., the developments in bookkeeping, record keeping, and accounting resulted in the emergence, especially in Italy, of double-entry bookkeeping employing base-10 Hindu-Arabic numerals. The Andes around this same time, from 1200-1400 C.E., witnessed the emergence of a tradition of cord-based (khipu, or quipu) accounting grounded in a base-10 number recording system that employed an elaborate system of checks and balances and shared many structural and operational features with contemporary European double-entry bookkeeping.

With the Spanish invasion of the Andes in 1532, the southern European tradition of double-entry bookkeeping - a system involving a continuous balancing of debits and credits - as well as Catholic notions of sin and sacramental confession, entered the Andes as elements of Spanish civil administration and ecclesiastical practice. The imposition of European religious values and rituals in the Andes set the stage for what can be characterized as history transpiring within a house of mirrors, with each of these two formerly unrelated traditions reflecting a perversely distorted view of the other. Soon after their initial confrontation, however, the southern European accounting system assumed a dominant position vis-à-vis the native Andean one. It is the extraordinary course of development of these parallel histories prior to 1532, as well as their transcultural confrontation, and mutual adjustment or accommodation following the Spanish conquest of the Inka Empire, that I will examine in this paper.

The material I will present has implications beyond merely adding heretofore uncharted content to the long list of arenas of social and cultural practices already recognized as implicated in the clash of civilizations following European conquest and colonization in the New World; it opens up a new patch of interpretive ground from which historians can survey the human intellectual, emotional, and psychological dimensions of that clash for people in the two newly convergent worlds. This new terrain is composed partly of mundane technologies and procedures of recording statistical information that were devised within the Euro-Iberian and the Andean societies, and partly of moral and epistemological rationales that linked those record-keeping systems with what were ultimately political projects of maintaining social 
order and structures of authority within these two early modern states. This study attempts to chart the contours of this complicated terrain.

While I have represented the timelines of the European and Andean accounting traditions as essentially contemporaneous, priority must be given to the European case. This is because so much of what we know about the khipu, the principal "bookkeeping" device used in Inka accounting, comes to us from testimony recorded by Spanish travelers, conquistadors, administrators, and clergymen. The historical record is already deeply compromised due to the absence of indigenous pre-Hispanic written accounts of Inka statecraft, record keeping, and governmentality. So as not to confuse matters further, I will begin with a discussion of the European case study.

SIN, CONFESSION, AND BOOKKEEPING IN LATE MEDIEVAL

WESTERN EUROPE

This study was stimulated by sociologist James Aho's recent book, Confession and Bookkeeping: The Religious, Moral, and Rhetorical Roots of Modern Accounting (2005). Addressing the question of the rise of capitalism and the origin of double-entry bookkeeping in southern Europe, Aho develops a thesis (some aspects of which I will later call into question) that runs directly counter to the views contained in Max Weber's classic study, The Protestant Ethic and the Spirit of Capitalism (1948). Weber argues that there was a direct, causal connection between the sixteenth- and seventeenth-century Protestant ethic, which emphasized, on one hand, the individuals' responsibility for their own salvation and the need to answer the "call" to do God's work, and ethical values and attitudes promoting hard work and profit-making in business that gave rise to and fostered capitalism, on the other. More specifically, Weber saw the preoccupation with personal salvation and the drive to follow a worldly "calling" that characterized the Puritan strain of Calvinism as lying at the root of the emergence in sixteenth- and seventeenth-century Europe of the rational capitalistic organization: of labor, the separation of the business from the household, and rational bookkeeping (1948: 21-24, 27). By "rational bookkeeping," Weber specifically meant the double-entry method. There are two curious circumstances in connection with Weber's argument for a causal connection among double-entry bookkeeping, capitalism, and Protestantism: first, the double-entry method appeared in northern Italy some three to four hundred years before the signal events marking the beginning of the Protestant reformation in central and northern Europe; and second, the Italian city-states in question were thoroughly Catholic.

The latter point speaks to a conundrum arising from the Weber thesis, particularly his assertion that medieval Catholicism was inimical to the mentality, life strategies, work ethics, habits, and values of capitalism (1948: 38-39). Weber argued that the individual Catholic felt no personal calling to do God's work in the world (except for the monk, who actually withdrew from 
the world) and that, therefore, the individual lay Catholic felt no drive to work obsessively for personal salvation. Weber believed that medieval Catholicism was mired in an ethic of dependency, with the salvation of the individual dependent upon the clergy's celebration of established rituals and ceremonies. The position taken by Aho (and before him, Werner Sombart) ${ }^{1}$ on the Weberian thesis is that late medieval Catholicism did, in fact, contain the stimulus for the development of capitalism and accounting that Weber claimed was absent. In particular, Aho argues that to the extent that double-entry bookkeeping was, as Weber argued, crucial to the rise of capitalism, the origin of this accounting method was in the bookkeeping practices devised from the thirteenth to fifteenth centuries C.E. in and for the dynamic mercantile capitalist principalities of northern Italy. Aho situates the stimulus for the invention of bookkeeping procedures and the accompanying rhetorical tropes rationalizing double-entry bookkeeping in the imposition on the Catholic faithful of auricular confession. The sacrament of confession, with its link to penance in expiation of sinful acts, was imposed in 1215 by Pope Innocent III in the Fourth Lateran Council.

This is not to say that either the concept of $\sin$ or the practice of confession and penance only came into existence or became formalized in church ideology and practice in the thirteenth century C.E. As Tentler (1977) has shown, evidence for earlier confessional traditions, such as canonical penance and a later Irish penitential tradition (Murray 1993; Tentler 1977: 16-18; Aho 2005: $12-15)$, is found in documents beginning in the second century C.E. and continuing on through the Middle Ages from the British Isles to southern Europe. Rather, it was the particular form of the sacrament of confession and penance that became mandatory after 1215 . Whatever their particular form, all confessional traditions shared certain values and objectives, including an emphasis on asceticism, worship, and charity, as well as the goal of reintegrating the sinner back into society following confession and the performance of penitential acts (Tentler 1977: 12-13). What has consistently been recognized as the principal objective of confession and penance in Catholicism is the effort to bring the sinner back into a positive and productive relationship with the Church and, hence, society. The principal means for achieving that reintegration were the sacraments administered by a priest acting under the authority of an overarching temporal-religious figure, the Pope.

With the imposition of compulsory confession on the Catholic faithful following the Fourth Lateran Council, priests began urging confessants to keep complete and accurate records of their sins. Aho argues that the practice of making notes for making a confession provided the model for business

\footnotetext{
1 Many of Aho's objections to Weber's thesis were at the core of arguments advanced earlier by Werner Sombart (1967). It is important to note that Yamey (1964) rejected Sombart's thesis of a causal connection between double-entry bookkeeping and capitalism.
} 
accounting, especially in terms of the balancing of debits and credits, as in double entry:

DEB [double-entry bookkeeping] arose from a sense of indebtedness on the part of late medieval merchants toward creator, church, and commune. Burdened with this debt, they felt compelled to certify in writing that for everything they earned something of equal value had been returned, and that for everything meted out something else was deserved. Many terms can be used to enframe this sense of indebtedness: "finitude," "limitedness," "creatureliness," "animality," "death consciousness," "lack," "existential evil" and "sin". ... As to the question, what instilled in the merchant's soul such an overweening awareness of personal sin, my answer is: the Roman Catholic sacrament of private penance, or as it is popularly known, confession. Far from being coincidental, the introduction of compulsory confession in 1215 and the appearance of DEB soon thereafter are meaningfully, if not strictly causally, related (2005: xiii-xiv).

Unfortunately, just as Weber was off by a couple of centuries in his claims for a link between double-entry bookkeeping and the rise of capitalism, Aho has underestimated the antiquity of the method in Italian mercantile bookkeeping practice. The earliest known pages displaying the double-entry format appeared in the cartulary (a notarial recording of legal documents) of a Genoese notary, Giovanni Scriba, in 1154-1164. Scriba's double entries are so sophisticated that it is clear they were an advanced stage of a development in bookkeeping that had been going on for some time (Epstein 2001: 55), though for precisely how long we cannot say. Aho briefly discusses the Scriba documents, but seems not to have given them their due significance (2005: 56). That is, if, as Epstein, Peragallo (1938), and others have argued, the Scriba cartulary papers from 1154-1164 contain a well-developed version of the double-entry method, then the causal connection asserted by Aho between the 1215 introduction of compulsory confession and the appearance of double entry cannot be sustained.

However, where I think Aho clearly got the matter right is in terms of an intensification of the use of the method in relation to the signal event of the imposition of auricular confession. The two practices, products of a similar scrupulosity in record keeping, reinforced and drew strength and supporting rationalization from each other. Lester Little has pointed to a similar process in his highly informative discussion of the emergence of the Mendicant orders - the Franciscans and Dominicans - in northern Italy around the time of the Fourth Lateran Council. As Little notes, "The friars ... reflected the society they entered by their frequent use of a marketplace vocabulary..." (1978: 200). Thus, while I do not think we can accept the causal link Aho postulated between the imposition of auricular confession and the appearance of double entry, there was clearly an intimate and long-term interconnection between the two.

Northern Italian accounts formatted in double entry, making use of the standard set of three entry books (see below), appeared with increasing regularity in the communes of Genoa (1340), Florence (1380), and Venice (1406; see Peragallo 1938: 3-37). The earliest description of double entry-including a 
discussion of the three essential books: ledger, journal, and memorandum book - appeared in a work by the Dalmatian Benedetto Cotrugli in 1458 (not published until 1573). Cotrugli declined to discuss the method in great detail, saying that it could only be learned with the aid of oral teaching (Peragallo 1938: 54-55). The earliest full explication and rationalization of the method appeared in 1494, in Luca Pacioli's, Particularis de Computis et Scripturis (Brown and Johnston 1984).

As Pacioli noted, the distinguishing characteristic of double-entry bookkeeping is the recording of transactions twice, once as a debit and once as a credit. Such postings are made on a pair of facing pages, or parallel columns on a single page, in which the debit entry is shown on the left side, the credit entry on the right. What ultimately appear as double-entry postings in a book called the Ledger begin as records in a pair of books, the Memorandum (or Daybook) and the Journal (Carruthers and Espeland 1991: 57-58). Pacioli wrote, "The Memorandum [or Daybook] . . is a book in which the businessman records all his transactions, large and small, in chronological order regardless of their size" (in Brown and Johnston 1984: 36). The daily, discursive postings to the Daybook are transferred to the second book, the Journal. The representation of transactions becomes more highly formalized in the Journal entries, pointing toward the even more formalized format and rhetoric of the Ledger (Figure 1).

As Aho observes, the discursive information in the Daybook was identical to the types of information sought by priests in confessional interrogations - quis (who), quid (what), cur (why), quando (when), quantum (how much), cum quo (in whose presence), and quo modo (how); these same forms of information were also gathered in the preparation of legal defenses and prosecutions (2005: 64). As a recording genre aimed at accounting for financial actions, double-entry accounts take shape in accordance with classical rhetorical procedures for constructing a convincing argument, particularly those found in the Ciceronian rhetorical tradition (Carruthers and Espeland 1991: 38; Aho 2005: 63ff.; see Thompson's 1991 critique of the argument for a link between rhetoric and accounting).

The linked accounting practices and rhetorical forms of double entry spread throughout Europe over the course of the thirteenth to fifteenth centuries, during which time they found a home in the emerging Spanish state of Ferdinand and Isabella. It was this tradition, which developed on the Iberian Peninsula during the late fourteenth through the fifteenth centuries, that the conquistadors and colonial administrators would carry into the Andes in the sixteenth century.

DOUBLE-ENTRY BOOKKEEPING IN SPAIN AND IN ITS

NEW WORLD COLONIES

The bureaucratic institutions and governmental structures of the state administration of Ferdinand and Isabella were inherited from the Catalan-Aragonese 


\section{Hypothetical Medieval Ledger Postings based on Luca Pacioli's Directions}

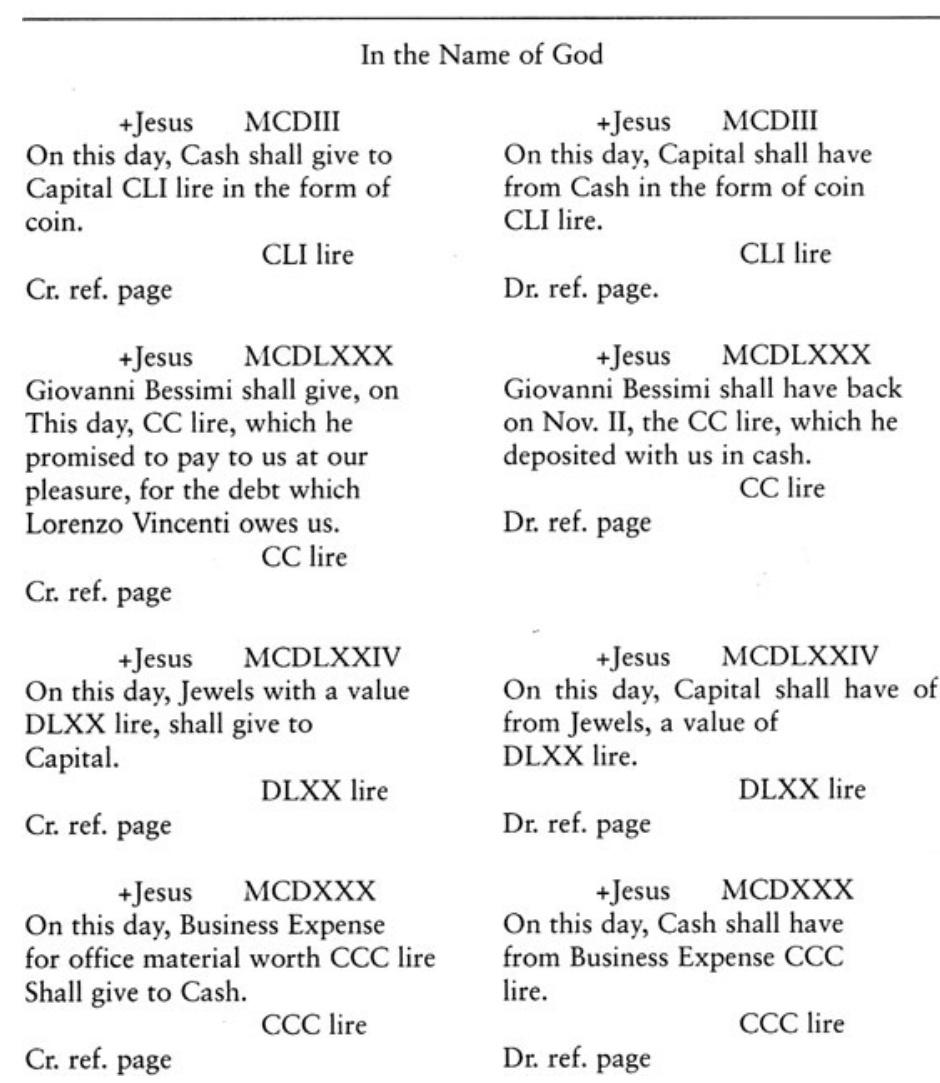

Figure 1 Sample Ledger Postings (Pacioli). Reproduced with permission from James Aho.

empire of the later Middle Ages. Central features of this governance system included a court that was in almost constant motion around the country (Elliott 1989: 18), and a conciliar system of governance, which included councils of state, justice, and finance (Mariéjols 1961: 151-53). The king and queen were represented in the territories by viceroys, who were required to submit regular reports to the royal council (Elliott 1989: 15). The crown's interests in the countryside were also overseen by a captaincy, composed of a cadre of military commanders who were required to follow elaborate accounting procedures (Stewart 1969). Each captaincy was assigned an accountant (contador), a group of paymasters (pagadores), and an inspector (veedor). Following the successful campaign to drive the Moors out of Granada, Ferdinand's chief 
civilian lieutenant, Fernando de Zafra, reorganized the Spanish military bureaucracy. The rationale for this reorganization was for convenience in record keeping (ibid.: 282-83).

The sources indicate that during the decades leading up to Spain's conquests in the New World the Spanish bureaucracy was undergoing expansion and rationalization leading to higher levels of formality and greater regularity in procedures (Mariéjol 1961; Phelan 1960). In addition, Spain's overseas conquests resulted in an explosion of bureaucratic procedures and documentation.

Double entry was known in Spain at least a century or so before this early modern nation came into possession of vast overseas holdings. Spanish accountants either traveled to Italy to learn the use of Hindu-Arabic numerals and the double-entry method with the accounting masters, the maestri d'abbaco ("reckoning masters;" Swetz 1989: 16), or instruction was provided by itinerant accountants who themselves had studied with these masters. The Genoese, who as we saw earlier were using double entry by the twelfth century, formed an important segment of Spanish mercantile communities beginning in the thirteenth century (Lopez 1987: 99-101), and their numbers increased substantially in fifteenth- and sixteenth-century Seville (see Pike 1966). The Spanish wool and textile industries of the thirteenth through fifteenth centuries employed sophisticated bookkeeping methods. Officials (the mayorales) oversaw the annual movement of great flocks of sheep, in an institution known as the Mesta (Phillips and Phillips 1997: 34-37). Wool merchants who traveled to the winter grazing areas recorded transactions in books called libros de la sierra ("books of the back country") using a double-entry format (Phillips and Phillips 1997: 174).

Beyond these field-based uses of double entry, Phillips and Phillips have noted that as early as 1465 merchants in the city of Burgos used northern Italian business models, as well as double-entry bookkeeping (1977: 169-70; see Reitzer 1960: 216, 221). Double entry was also employed in record keeping of Spain's financial relations with its American colonies, as seen in the sixteenthcentury accounting records of the minting of gold and silver in the Casa de la Contratación (the agency overseeing Spanish-American trade) in Seville. From his study of the Casa records for 1560, Donoso Anes found that entries were made in four different books, two of which - the Diary Book, or Manual, and the Ledger Book, or Libro de Caxa-were registered in doubleentry format (1994: 102-3). The Diary was equivalent to Pacioli's Memorandum book, in that it contained the day-to-day listing of transactions. Diary Book entries were posted to the Ledger, the Libro de Caxa, on two facing pages: the left-hand page for debits, the right-hand for credits (ibid.: 106). Since Spain was a Catholic nation, we might expect that the interconnection found in late medieval northern Italy among mercantile capitalism, double-entry bookkeeping, and an intense concern with sin and confession might have been operative in Spain as well. 
To say that Spain was a Catholic nation at the time of its New World conquests is, of course, an understatement. The justifying mission of the Spanish crown and ruling class was "to uphold and extend the [Catholic] faith, bringing to a civilized and Christian way of life ... all those benighted people who, for mysterious reasons, had never until now heard the gospel message" (Elliott 1989: 9). As the site of the formation and institutionalization of the Inquisition, in 1480, the Spanish state and society were suffused with Catholic ceremonies and the observance of sacraments directed by members of an astonishing number and variety of religious orders, as well as by the secular priesthood. Not the least among the sacraments observed by Spanish Catholics in Spain and in the Americas was the performance of auricular confession. With the institution of compulsory penance in the thirteenth century, Catholics in Spain and elsewhere began increasingly to exhibit what Aho and others term a moral scrupulosity, "a dread that even an off-hand word, thought or deed might, if undivulged to the priest, be the one that occasions eternal damnation" (Aho 2005: 23; see also Tentler 1977: 76). In this context, one of the cornerstones of the sacramental system of consolation was the enumeration of sins. As Tentler writes, "Defining and telling sins was as relevant to discipline as to consolation. It represented an inventory of undesirable behavior ... and the ultimate goal ... was the elimination of all items in the inventory..." (1977: 134).

Scrupulosity in accounting for sinful thoughts and actions was transported into the New World in the baggage of the clergy and their agents of pacification, the conquistadors. The stage was thus set for a confrontation between this "Old World" tradition of accounting and preoccupation with religion and transgressive behavior (i.e., sin) and any such traditions that they might encounter in the "New World." What accounting traditions did the Spaniards meet with in the Andes? If complex accounting did indeed exist in the pre-conquest Andes, is there any evidence that the Andean tradition emerged in relation to notions of "sin," acts of "confession," and perhaps even a native version of "scrupulosity?" Let us take a closer look at the Inkan system.

\section{THE INKAN KHIPU AND ITS METHODS OF INFORMATION REGISTRY}

Archaeologically, the Inka Empire is recognized as a collection of forms and styles in architecture, ceramics, textiles, metals, and other media found at sites within the expanse of territory stretching some 5,000 kilometers along and on either side of the Andes, from the Colombia-Ecuador border in the north, southward to about 200 kilometers south of Santiago de Chile. The Spaniards viewed the Inka state as a great empire, overseen by a divine lineage (the ancestor/founder claimed descent from the Sun), and they often compared it to the Roman Empire (see MacCormack 2007). The Inka and his family stood at the pinnacle of a hierarchical, militaristic society that began expanding from its capital at Cusco, in the southern highlands of present-day Peru, 
around 1400 C.E. (see D'Altroy 2003). The time from the coalescence through the early expansion of the Inka state coincided approximately with the period from the Fourth Lateran Council in 1215 until the publication of Pacioli's text in 1494.

The Inka Empire has fascinated archaeologists, perhaps most notably for the absence in Andean political economies of money, markets, and a graphic, sound- or language-based writing system. The latter absence has been a problem for us in our attempts at decipherment, but for the Inkas, their threedimensional khipu recording device was entirely adequate for maintaining state records. Below, I will address the kinds of information the Inkas recorded, how they registered that information in khipus, and the significance of khipu record keeping in the comparative, global history of accounting and bookkeeping. But first let me provide an overview of how information was recorded on these remarkable, knotted-string devices.

Khipus are made of spun and plied cotton or camelid fibers. ${ }^{2}$ The colors displayed in khipus are the natural colors of these fibers, or those of applied natural dyes. The backbone of a khipu is the so-called "primary cord"-usually around $0.5 \mathrm{~cm}$ in diameter - to which are attached a variable number of thinner strings, called "pendant cords" (see Figure 2). Khipus contain from one to as many as fifteen hundred pendants (the average of some 450 samples studied by the Harvard Khipu Database project is eighty-four). Attached to about one-quarter of all pendant cords are second-order cords called "subsidiaries." Subsidiaries may themselves bear subsidiaries, and some khipu contain up to six subsidiary levels, making them a highly efficient device for the display of hierarchically organized information (see Ascher and Ascher 1997; Urton 1994; 2003).

The majority of khipus have knots tied into their pendant and subsidiary strings. The knots, generally of three distinct types, are commonly tied in clusters at different levels in a decimal place system of numerical registry (Locke 1923). The arithmetic and mathematical operations used by Inka accountants included, at a minimum, addition, subtraction, multiplication, and division; division into unequal fractional parts and into proportional parts; and multiplication of integers by fractions (Ascher and Ascher 1997: 151-52; Urton 2003).

Although we are able to interpret the quantitative data recorded in khipu knots, we are not yet able to read any accompanying nominative labels. Specialists think that such information was encoded in various ways, including by colors, numbers (read as "labels"), and cord and knot construction (Urton 2003). In discussing the possible identities of objects accounted for in the khipus, we are forced to rely on Spanish accounts from the early years

\footnotetext{
2 According to my own inventory, there are some 790 khipu samples in museums and private collections in Europe, North America, and South America. While many are too fragile to permit detailed examination, almost 450 have been closely studied to date. Observations on several hundred khipus may be viewed at the author's website: http://khipukamayuq.fas.harvard.edu/.
} 


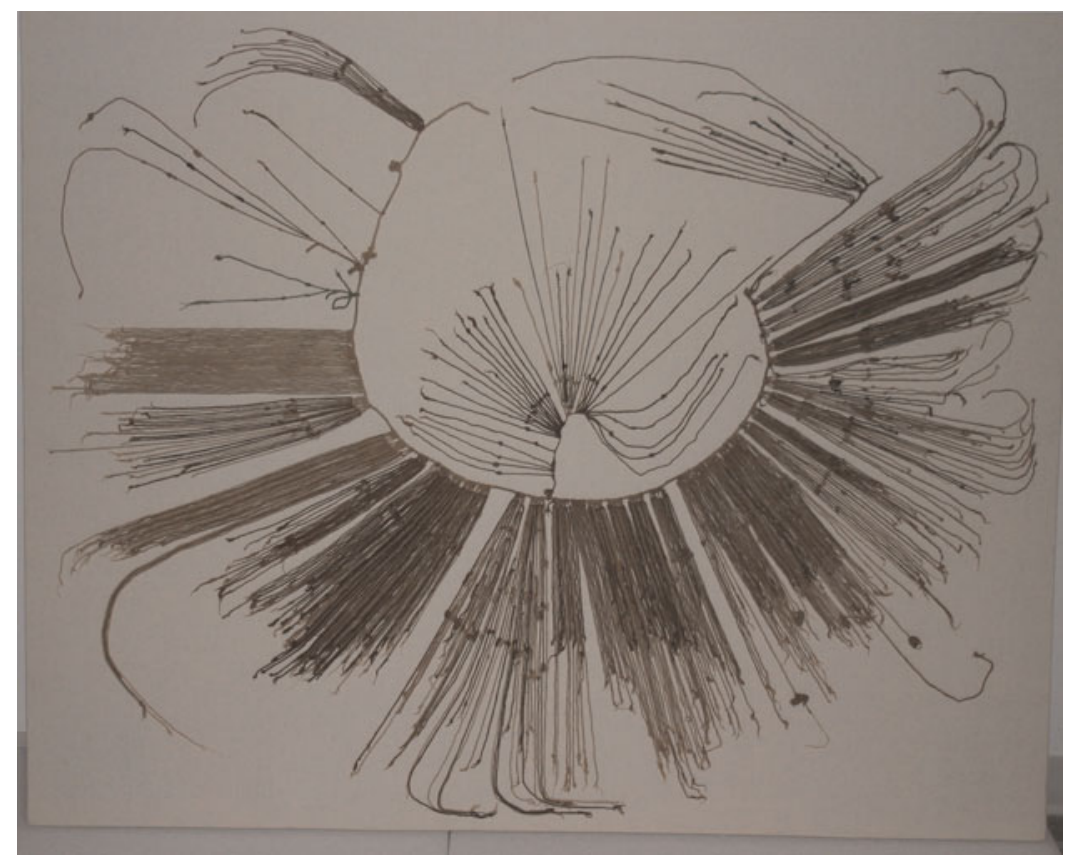

Figure 2 An Inka Khipu (Herrett Museum). Reproduced with permission from Herrett Center for Arts and Science, College of Southern Idaho.

following the European invasion. According to these accounts, khipu records were kept of, among other things, censuses, tributes assessed and performed, goods stored in the Inka storehouses, astronomical periodicities and calendrical calculations, royal genealogies, and historical events (see Julien 1988; Murra 1982; Urton 2001; 2003; 2006). Perhaps most important to the Inka state were the census records from which its revenues were calculated, particularly the labor tributes owed by subjects.

\section{DEBIT AND CREDIT ACCOUNTING IN THE INKA EMPIRE}

Inka "tribute" took the form of a labor tax levied on all able-bodied men from ages eighteen to fifty (D'Altroy 2003: 265-68). Khipu census records provided the information for the assessment and assignment of corvée laborers (Julien 1988; Murra 1982). Every "taxpayer" (i.e., state laborer) was required to work on state projects for a specified period of time each year, building and maintaining buildings, roads, bridges, and storehouses; spinning and weaving; guarding the herds of the Inka, participating in military campaigns, or performing other tasks (see Cieza de León 1967 [1553]: 62; LeVine 1987; Murra 1982). 
For labor and accounting purposes, workers were (ideally) organized in a hierarchical arrangement of decimally based groups, composed, cumulatively, of ten, fifty, one hundred, one thousand, and so forth up to ten thousand workers. Near the top of the administrative hierarchy overseeing these work groups were the governors, called t'uqrikuq ("overseers"), of each of the approximately eighty provinces that made up the empire. Among other duties, the t'uqrikuqs were responsible for the collection of provincial census data and passing information up the administrative chain (Pärssinen 1992: 257-87; Urton and Brezine 2005).

The khipu was the instrument for recording what was owed and what had been "paid" - that is, what corvée assignments had and had not been performed. In fact, we have an intriguing statement by the mestizo (i.e., of mixed Quechua and Spanish ancestry) chronicler Garcilaso de la Vega describing an arrangement for earning labor "credit" on tasks to be performed from one year to the next: "Each craftsman was ... only obliged to supply his labor and the time needed for the work, which was two months, or at most three. This done, he was not obliged to work any more. However, if there was any work left unfinished, and he wished to go on working of his own free will and see it through, what he did was discounted from the tribute he owed for the following year, and the amount was so recorded by means of their knots and beads" (Garcilaso 1966: 273; my emphasis).

This system necessitated complicated bookkeeping practices involving the careful notation, in knots, of labor debits and credits. ${ }^{3}$ It would have required two features: a method of performing checks and balances, and a way of distinguishing debits from credits. As for the former, Garcilaso de la Vega noted, "The Inca governor of each province was required by law to keep a copy of the accounts in his possession so that no deception could be practiced by either the Indian tribute payers or the official collectors" (1966: 274, my emphasis).

Concerning the recording of debit and credit accounts, whether in khipus or other notational formats, a fascinating study by Tristan Platt describes accounting in the late pre-Hispanic Aymara kingdoms of the altiplano, or highlands, of what is today central Bolivia. Aymara record keepers kept track of transactions by exchanging small stones signifying debits and credits. For any particular transaction, a black stone, called cchaara, signified a debt, while a white stone, called hank'o (or ch'iyara), signified the loan that established the debt

\footnotetext{
3 Three articles published in the 1960 s and 1970 s by economists and historians of accounting contain a brief but lively debate about whether or not the khipus contained double-entry bookkeeping. In the first of these articles, Jacobsen (1964) argued that the Inkas may have invented the double-entry method. Forrester (1968) and Buckmaster (1974) disputed Jacobsen's claim. There is not space here to review the arguments made in these three articleş but suffice it to say that, while interesting for historical purposes, their authors are poorly informed about the nature of the khipus and about testimony in the Spanish documents concerning knotted-string record keeping in relation to Inka political and economic institutions.
} 
represented by the black stone. The pairing of black and white stones represented a system in which loans and debts were maintained in a balanced state. However, hierarchy was also a salient feature of this accounting system, and the person who held the white stone was in a superior position vis-à-vis the person who held the black stone (Platt 1987: 86-87). The active, on-the-ground system of registering debit/credit accounts could have been recorded on khipu - or chino in Aymara parlance - in more permanent registries of debit/credit records for archiving by administrative officials.

Do extant khipu samples give us insights into how complex accounting, such as labor debits and credits, might actually have been recorded? More specifically, is there any evidence that khipu-keepers made use of their cord-keeping devices and double-entry-like accounting methods in connection with notions like the concepts of sin and the practice of confession and penance in contemporary Spanish Catholicism? If we were to find evidence for double-entry-like accounting in pre-Hispanic Andean khipu records, how might we explain the invention of that "rational" accounting method in this New World setting? Before fretting about something that is, at this point, merely hypothetical, we must evaluate whether or not such a method of registration-that is, double-entry-like recording - existed in the khipus.

\section{KHIPU COPIES: DUPLICATE ACCOUNTING OR "DOUBLE-ENTRY" RECORDS?}

One of the most interesting khipu formatting features for our purposes involves duplicate, or "matching" khipus (Urton 2005). Matching khipus occur in three different forms. There are examples in which the numerical values recorded on knots on a sequence of strings on one sample are repeated exactly on another khipu. In some instances of this type, while the two khipus bear the same knot values, the string colors often differ. Such an arrangement could have been used to record, for instance, labor time owed (=debt) tied on cords of one color, and labor obligation fulfilled (=credit) tied on cords of another color. Another type of "duplicate khipu" formatting involves two different samples bearing not exact but rather similar numerical data. I refer to such examples as "close matches." Close matches could represent accounts in progress - ones in which debits and credits had not yet been balanced. For instance, such a pair of khipus might have indicated accounts in which labor owed had not yet been fully performed, or in which a labor credit had been accumulated. Finally, we have examples of duplicate accounts in which the numerical data recorded on a sequence of cords on one section of a khipu are repeated exactly, or closely, on another section of that same sample (see Urton 2005 and 2006). Such a khipu could have been kept by a single khipu-keeper who was responsible for knotting information on debits and credits on a single khipu.

We have a remarkable historical account of this third type of khipu. Hernando Pizarro, Francisco Pizarro's brother, tells us that on one occasion, in 
1533, when he and his soldiers took items from an Inka storehouse along the royal highway, the accountants - khipukamayuyq ("knot-maker/keeper") recorded the transaction on a knotted-string recording device: the record keepers "untied some of the knots which they had in the deposits section [of the quipu], and they [re-]tied them in another section" (1920 [1533]: 175; see also 178). This sounds remarkably like an act of "balancing the books" in a double-entry-like khipu accounting format.

I have argued previously (2005) that duplicate, and even triplicate copies of khipus are evidence of a general system of "checks and balances" in khipu accounting, and that close matches perhaps resulted from paired (e.g., moietybased) accountants using different methods of counting, or of counting and recording information at different times. I suggest now that it is equally likely that duplicate accounts might have represented a system of double-entry-like accounting. I believe that paired, duplicate khipus contain the requisite elements of double-entry accounting, which involved recording all transactions twice, once as a debit and once as a credit. The principal information we lack in order to make such a determination are the identities of the objects recorded on the khipus. Since we still cannot read the code of the khipus (if, indeed, they are "readable"), we cannot evaluate whether any given pair were simply copies or if they might represent a relationship between a debit for an item on one account and the credit for that same item on another account.

Evidence pointing toward the kind of accounting I have proposed for the khipu is found in a few of the transcriptions of these records made in early colonial times. Such transcriptions were made on those occasions-increasingly common through the sixteenth century - when native cord accounts (e.g., of tribute records) differed from the Spanish written accounts, and disputes arose over the items in question. In such circumstances, courts often arranged for the transcription of khipus by their native keepers (see Urton 1998; Pärssinen and Kivijarhu 2004). One fascinating transcription, relating to cord accounting in the Province of Lupaca on the western shores of Lake Titicaca, involves the recording of information on various quantities of camelids that were "taken in" (ingresado) as a "charge" (cargo) by the Lupaca herders, on one hand, and an accounting of how those animals were disposed of, or "discharged" (descargo), on the other. In the transcription of this khipu (see Figure 3), the numbers of camelids that were taken in as cargo are listed on the right-hand side of the page, while the (equivalent) numbers of those discharged are listed on the left-hand side. My presumption is that just as the scribe who wrote out this document used a double-entry-like credit/debit type format, in which cargo values were placed on the right and the descargo values on the left, so too would the khipu-keepers have maintained different, linked debit [cargo]/credit [descargo] sections in his cord account (Pärssinen and Kivijarhu 2004: 247-67).

In sum, it seems clear that khipus had all of the signing complexity and the recording capacity needed in order to register double-entry-like accounts. The 
[fol. 1 r.] Relaçión del ganado que pareçe aver entregado Juan Vásquez de $/{ }^{2}$ Tapia y Diego Pacheco a estos caçiques de Chucuyto y sus prouincias $/{ }^{3}$ por de su magestat juntamente con el descargo que los dichos caciques $/{ }^{4}$ dan por sus quipos de lo que se ha fecho del dicho ganado.

\begin{tabular}{|c|c|c|}
\hline \multirow{6}{*}{ Carneros grandes } & $/{ }^{5}$ Chucuito cargo & \multirow{4}{*}{$\operatorname{CCCLXXX}^{\circ} \mathrm{VII}$} \\
\hline & ${ }^{16}$ Tiene este pueblo de su magestat en guarda & \\
\hline & $/ 7$ entregados por Juan Vásquez de Tapia trezien- & \\
\hline & $1^{8}$ tos y ochenta y siete carneros grandes. & \\
\hline & $/{ }^{9}$ Más les dio en guarda Pacheco ochenta & \multirow[t]{2}{*}{$\mathrm{LXXX}^{\circ} \mathrm{VIII}{ }^{\circ}$} \\
\hline & $/{ }^{10} \mathrm{y}$ ocho carneros grandes. & \\
\hline & & $\mathrm{CCCC}^{\circ} \mathrm{LXXV}$ \\
\hline \multicolumn{3}{|c|}{ / ${ }^{11}$ Descargo que dan por sus quipos } \\
\hline & ${ }^{12} \mathrm{Q} u e$ les tomó Çenteno quando fue a dar la ba- & \\
\hline \multirow[t]{2}{*}{$\mathrm{XCVIII}^{\circ}$} & $/ /^{13}$ talla de Guarina noventa y ocho carneros & \\
\hline & $/{ }^{14}$ para cargas. & \\
\hline \multirow[t]{3}{*}{$\mathrm{XXIIII}{ }^{\circ}$} & / ${ }^{15}$ Más les tomó otros veyntiquatro carneros & \\
\hline & $/{ }^{16}$ para cargas en el Desaguadero. & \\
\hline & $/{ }^{17}$ Que les tomó Gonçalo Piçarro para lleuar al Cuzco & \\
\hline \multirow[t]{2}{*}{$\operatorname{CCLXXX}^{\circ} \mathrm{I}$} & $/{ }^{18}$ duzientos y ochenta y vn carneros. & \\
\hline & $/{ }^{19}$ Que dieron a Françisco de Caruajal quarenta & \\
\hline $\mathrm{XL}$ & $/{ }^{20}$ carneros. & \\
\hline XXXII & ${ }^{21} \mathrm{Que}$ se les han muerto treynta y dos. & \\
\hline
\end{tabular}

FIgURE 3 Khipu Transcription from Lupaca Territory.

question then becomes whether or not such accounting formats and procedures had salience and utility in relation to the monitoring of behavioral norms, and breaches of those norms, in the Inka state. ${ }^{4}$ That is, can it be said of the evolution of record keeping in the Inka state, as Aho has argued for the northern Italian principalities at around this time, that double-entry-like accounting arose in intimate relationship with the performance of "confession" in monitoring and seeking rectification and/or restitution for disruptive, "sinful" acts?

AN INTERLUDE: IS "SIN" UNIVERSAL?

It is a central contention of this study that there existed in late pre-Hispanic, Inka society a concept denoting forms of personal comportment that were considered by those in power-from the Inka to provincial governors down to local

4 See Salomon's discussion of the pairing of khipus and the possibility of double-entry-like accounting in the present-day community of Tupicocha (2004). 
headmen - to be destructive, antisocial, and threatening to the interests of the state. Such acts included the failure to perform, or the incorrect performance of, rituals in honor of the deities and ancestral mummies, and actions, such as murder, theft, and adultery, that were considered to threaten the stability and order of society. The term in Quechua - the lingua franca and language of administration in the Inka Empire - most commonly used to refer to such anti- or asocial behaviors was hucha, generally glossed in colonial Spanish/ Quechua dictionaries as pecado ("sin") and culpa ("guilt, fault"). Hucha is often linked with another term, cama, in a manner suggesting they were synonyms (Harrison 1992: 13-14). Glosses for cama evoke a range of meanings including "order," "animate," "create," and "negotiate/negotiation" (see Durston 2007: 215; Horsewell 2005: 212-13; Salomon and Urioste 1991; Taylor 2000). I will return to this lexical pair presently.

The reader may be skeptical of my suggestion that concepts whose roots reach so deeply into western European religious, social, and psychological formations as do "sin," "confession," and "penance" could possibly have grown up autonomously in the social, political, and psychic soil of a continent completely separated from Catholic western Europe. I argue that the two fifteenthand sixteenth-century societies that concern us here, the Spanish and the Inkan, both existed within states built up around institutions devoted to good governance and the maintenance of social order and control. In fact, every society, from the simple to the highly complex, devises techniques for the surveillance and monitoring of social behavior, as well as procedures for dealing with breaches of social norms and for reintegrating those who violate norms back into society. The issue, then, is not whether or not disorder and a- or anti-social behaviors are monitored and controlled within any given society, but rather how a given society defines misbehavior, what are considered to be the sources and consequences of disorderly behavior, how behavior is monitored, and what sanctions are placed on those who violate behavioral norms.

I argue that European and Andean moral and ideological concepts connected with what we term "sin," as well as their procedures for ensuring social stability by confronting forces of discord and disharmony, appear to have been based on similar premises: people often act in ways that threaten social order and stability, and left unchecked, such transgressive behavior can undermine society and lead to disruption. Both societies considered it essential to institute codes defining correct behavior and ethical norms, means for punishing those found guilty of violating the norms, and ways of affecting restitution and of reintegrating malefactors back into society. The solution arrived at, independently, in Europe and in the Andes was for the offending individual to confess to an established authority, and to seek pardon and/or perform acts of expiation (e.g., penance). I argue that prior to the time of contact, western European and Andean societies independently developed quite similar means for addressing asocial, transgressive behavior based on their respective 
traditions of "confession" followed by forms of punishment and/or penance. However, the two traditions differed radically in how they viewed the nature and location of transgressions - whether they were considered to be located in individual actions alone (as in the Andes), or in both the actions and thoughts of individuals (as in Europe; MacCormack 1991: 347). These and other differences caused no end of difficulties when, soon after the conquest, Catholic priests imposed their own understandings of "sin" and the sacrament of confession on native Andeans (Harrison 1992: 11).

The norms and procedures associated with the supervision and governance of individual behavior, as well as the discursive practices (e.g., data collection, organization, and reporting) by means of which such oversight and surveillance are conducted and come to dominate the routines of daily life, constitute what Foucault terms "governmentality" (2000 [1978]: 219-20). This term refers to discursive programs and regimes of social control-what Foucault refers to as systems of "power-knowledge" - that take the form of institutions that act on, and regulate the behavior of, individuals. In the Inka state, such institutions would include the census, the corvée system, the age grades, and rituals linking commoners to the Inka and the state religious hierarchy. Governmentality is a form of power, but it is not like the power resulting from the coercive force of police or a militia; rather, it is the power of the routine; the standardized format; the commonly accepted, expected way of doing things; the turn in a rotational sequence, etcetera. While Foucault developed the concept of governmentality in relation to regulatory apparatuses, forms of knowledge, and discursive programs that arose especially during the Middle Ages in western Europe, a similar evolution occurred in the Andes at around the same time, or at least we find markers of society having arrived at a similar endpoint: a preoccupation with statistics, political arithmetic, institutions for monitoring and regulating individual and group behaviors, and so forth. It is the historic clash, the "conjuncture," between these two systems of governmentality that concerns us here.

TRANSLATING THE LANGUAGE OF SIN, CONFESSION, AND RECORD KEEPING

We must first consider how a language pertaining to Inka notions of sin and confession took shape within the Spanish colonial textual tradition. Because we have no pre-Hispanic discursive accounts concerning sin, confession, and khipu recording, we must rely for our principal sources of information on the early Spanish documents, with their invented, adopted, and hybridized vocabularies. Beginning in the earliest days following the conquest, the Spanish clergy showed great enthusiasm and commitment to preaching the Word and instructing native Andeans in church liturgy and the sacraments. The priests urgently needed a common language for this purpose. While they hoped, initially, to be able to instruct a significant number of natives in Spanish or Latin (Durston 2007: 55; Harrison 1992: 7), it soon became apparent that 
they possessed neither the resources nor the control over the population essential to teaching language on such a scale. Instead, the Spanish clergy sought to gain fluency in native Andean languages. Quechua, and to a lesser extent Aymara, were selected as the principal languages of evangelization for reasons that are well documented elsewhere (see Durston 2007: 67-75, 105-15; Mannheim 1991).

Reliance on Quechua as the primary language of proselytization and instruction raised important challenges. These involved the production of manuals for instruction (e.g., catechisms, sermons) in Quechua and, more specifically, the identification of terms in Quechua that could serve as appropriate translations for key liturgical and catechetical terms. If appropriate translations could not be found, the alternative would be to leave key terms in the original and teach their meaning through analogy, metaphor, and other tropes and rhetorical strategies in the language of instruction (see discussions of these issues in Durston 2007; Estenssoro Fuchs 2003; and Mannheim 1991). ${ }^{5}$

Many of the central issues of language use and translation were raised and resolved (though often only temporarily) in three sixteenth-century provincial councils of churchmen. The principal council, in terms of its enduring influence on the colonial church in the central Andes, was the Third Provincial Council of Lima, held in 1583-1584. The general compendium of documents published by this council, Doctrina Cristiana y catecismo para instrucción de indios... (1584-1585; see Durston 2007: 88-89), included a short treatise - an extract from a now lost manuscript - entitled Los Errores y supersticiones de los Indios Sacados del Tratado y averiguación que hizo el Licenciado Polo (Doctrina Christiana, 265-83). The original manuscript of this shorter work was authored by Polo de Ondegardo, a jurist, conquistador, encomendero (holder of a grant of Indians), and highly knowledgeable investigator of Inka religion and culture who lived in Cusco off and on from 1561 until his death in 1575 (Presta and Julien 2008). Ondegardo's extract includes a description of Inka confession and its relation to what he understood to have been a pre-Hispanic concept of sin. In reviewing Ondegardo, we must return to consider the semantics of hucha, cama, and the evidence for a pre-Hispanic form of confession.

THE ANDEAN CONCEPT OF HUCHA AND ITS RELATION TO ACCOUNTING

As stated earlier, Spaniards and Andeans together constructed a set of glosses on the Quechua term hucha describing behavior that Spaniards termed pecado ("sin"). For instance, the noted seventeenth-century Quechua lexicographer Diego González Holguín (1952 [1608]) glossed the terms pecar ("to sin”)

\footnotetext{
5 Burkhart's book The Slippery Earth (1989) is a magnificent study of the challenges faced by the clergy in preaching to natives and in producing instructional materials in Nahuatl for their efforts to convert the Indian populations of central Mexico.
} 
and culpa ("fault") using principally the Quechua term hucha. We gain a sense of the "sinful" behavior characteristic of Inka society from the mid-seventeenth-century chronicle of the Jesuit priest Bernabé Cobo, who took much of his information from the earlier writings of Polo de Ondegardo:

With respect to overt acts, they believed that there were many ways to $\sin [$ pecar]. Among the ones that concerned them the most were the following. Murder, except as an act of war, either by use of violence or by witchcraft and poisoning; stealing; carelessness in worshiping the guacas [sacred objects] and shrines; missing festivals and failing to participate in them with sufficient reverence; and cursing the Inca or not obeying him. Although taking another man's wife and seducing a maiden were both considered sins, it was not because they felt that fornication itself was a sin. These acts were considered sinful because they were contrary to the Inca's commandments (Cobo 1990 [1653]: 122).

While Cobo does not specifically mention the term hucha, the actions he describes as "sinful" (pecado) are similar to those that other contemporary sources specifically label by this term. In the chronicle of the first Augustinian friars in Peru, whose testimony dates back to 1551 , we see the equation between pecado/culpa and hucha, as well as a relationship between sin and confession: "The manner of confession was that they said their ochas [huchas], which in their language is what they call faults [culpas], and they confessed if they had stolen something or had quarreled or had not served well their lord [principal], or cacique, if they had not given proper respect to the devil [çupay] and demon and to the guaca [sacred object] or idol and had not done whatever the demon demanded. . . (San Pedro 1992 [1560]: 208, my translation).

Additional references to hucha evoking the Spanish concept of "sin" appear in the native chronicler Guaman Poma de Ayala's description of a two-tier hierarchy of specialized accountants in the empire. The upper level of this hierarchy was occupied by an official called contador mayor hatun hucha quipoc ("major accountant of the great 'sin' khipu'); at the lower level was the contador menor huchuy hucha quipoc ("minor accountant of the small 'sin' khipu;" Guaman Poma de Ayala 1980: 333). The accountants of "sin" were involved in negotiations between those found guilty of misdeeds (pecados) and native confessors (confesores). The confessors were involved in divining the cause, or source, of sinful behavior, often by examining the entrails of cuyes (guinea pigs; e.g., see San Pedro 1992 [1560]: 209). Cabello de Balboa (1951 [1586]: 259) states that Inka confessors required those guilty of "faults" (culpas) to perform penance ( penitencias). Hucha embraced a range of disorderly actions that went against the commandments of the Inka, the gods, and other sacred objects (huacas) and that, thereby, introduced disorder and conflict into society (Acosta 2002 [1590]: 304-5; Polo Ondegardo 1916 [1571]: 12-15).

Regina Harrison has observed that "hucha, as found in the context of indigenous culture, is often associated with what is owed but has not yet been settled up, sort of a debt to society kept track of on a large balance sheet" (1992: 13, my emphasis; see also Charles 2007: 28; Horswell 2005: 213). 
Harrison's gloss leaves little ground to be covered when we seek later to connect hucha with cord accounting. In his study entitled Decolonizing the Sodomite (2005), Horswell points out that, while pecado pointed to individual transgressions of the canonical laws and regulations dealing with personal conduct, hucha, in its aboriginal contexts, was concerned more with transgressions of reciprocal obligations between the individual and the community, or the individual and the Inka and/or the sacred entities known as huacas (2005: 212-13). ${ }^{6}$ This observation suggests why the Spanish clergy were troubled by glossing pecado as hucha, since the latter did not point in a sufficiently condemnatory manner to the personal failings, faults, and inner thoughts of the individual. This point is made by Bernabé Cobo in commentary on Inka notions of $\sin /$ hucha that immediately precedes the passage cited above: "It is a most astonishing thing to see that the devil had introduced the use of vocal confessions among these Indians. This custom was so universally accepted that it came to be one of their most common ceremonies, and it was practiced with much devotion. They confessed everything that they understood to be a sin. However, they were quite mistaken in the opinion they held about sin. In the first place, they never paid any attention to what went on in a person's mind, such as perverted desires or inclinations. Such things were neither mentioned in confession nor were they considered to be sins" (1990: 122).

Thus, in the pre-Hispanic Inka world, "sin" was not recognized in the kinds of "immoral," and especially sexual thoughts with which the Catholic clergy were so concerned (see Tentler 1977: 153-56, on "sinful thoughts"). Rather, Inka $\sin /$ hucha referred to acts of social discord and disharmony-for example, a person's failure to perform, or the flawed performance of, ritual duties; to the subversion of the common good; and even to the act of laboring for one's self rather than for the community's benefit (Harrison 1992: 13). Acts of hucha were troublesome because they manifested a failure to recognize and adhere to the obligations of reciprocity expected of individuals toward the community, the state authorities (both local lords and the Inka), and the gods. ${ }^{7}$

\footnotetext{
${ }^{6}$ I would observe here that, while Durston has argued that the Andean concept of hucha applied to the actions of collectivities (e.g., perhaps social groups, such as ayllus) rather than to individuals (2007: 287), I do not find this conclusion supported by my own study of the documents, nor is such a conclusion supported by Harrison's close reading and analysis of the relevant sixteenth- and seventeenth-century texts (1992). For further commentary, see note 7.

7 This discussion carries us close to what is a highly controversial subject in the study of European confession. Much of the controversy relates to an article by John Bossy (1975) in which he attempts to make the argument that the sacrament of penance before the time of the Reformation related to the significance for the community of sinful acts committed by individuals, whereas, with the Counter-Reformation, the focus shifted ". . . away from the field of objective social relations and into a field of interiorized discipline for the individual" (1975: 21). I raise the issue not to get drawn into this Europeanist controversy (as I am not qualified or knowledgeable enough to hold a strong opinion on the matter), but rather because a similar issue exists in the Andes (see note 6). In the Andean case, the question concerns the focus on community harmony in pre-Hispanic conceptions of confession and an apparent shift to a focus on the individual in the post-conquest
} 
I suggested earlier that in order to understand the meaning of hucha in Andean terms, we would need to take account of the relationship between hucha and cama. ${ }^{8}$ The two words are often juxtaposed in colonial Quechua dictionaries. For instance, the seventeenth-century Quechua/Spanish dictionary of González Holguín gives the following glosses (among others): Hucha, or cama. ("sin, or business or legal action" [Peccado, o negocio o pleyto]); Hucha huacllik ("he who/that which would obstruct, impede, and endanger everything good, and take advantage of [profit from] others and perturb their plans, or be contrary to, or an impediment of a union of love and the peace of others, or the cause of disunion, he who does not work for the good of others but for himself"); Huchalliccuni ("to sin" [pecar]); Camallicuni, huchalliccuni ("to sin" [ pecar]); Camak Dios ("God the creator" [Dios criador]); Camachini camachicuni ("to order, or consult; that which has been ordered"); Camani ("to carry to productive fruition, to create"); and Camay ("my obligation; duty" [mi obligación]) (Gónzalez Holguín 1952 [1608], my English translations). How are we to understand the meaning of these two terms, and why and how they were considered so linked to each other as to be given (seemingly) as synonymous?

Harrison begins to move us in a useful direction when she observes that cama carries generally positive attributions, "often [being] linked with the source of an animating force originating from a regional deity or an ancestor," while hucha has a negative connotation, being associated with destructive forces (1992: 13-14). She states, "Cama conveys the meaning of putting things in place as opposed to the breaking up of order as seen in hucha" (1992: 14). The matter takes on greater clarity when we turn to Frank Salomon's comments on the uses and forms of cama in the early-seventeenth-century Quechua document known as the Huarochiri Manuscript (Salomon and Urioste 1991). He argues that, in the genetive form, camac, the term refers to a "vitalizing prototype." For instance, the dark cloud constellation of the Llama is referred to in the document as the camac of llamas, which Salomon glosses as the powerful generative essence that causes earthly llamas to flourish (ibid.: 16).

In this reference to reproductive vitality we find a slim edge to grasp in trying to understand at least one aspect of the relationship between cama and hucha. In this vein, one of the central characters in the Huarochiri Document, a woman named Chaupi Namca, is said to have had a mighty sexual appetite. It is said

\footnotetext{
Andean world. In both cases - the European and the Andean-I suspect that what was at issue were shifts in degrees of emphasis rather than in absolute differences.

${ }^{8}$ For instance, in his book Camac, Camay y Camasca, Gerald Taylor states that hucha and cama were related (2000: 3 ). However, he does not comment further on the possible meaning or significance of the pairing of these terms.
} 
that "In the old days, this woman used to travel around in human form and used to sin with [uchallicuc carcan] the other huacas ['sacred objects/places']" (Salomon and Urioste 1991: 78). Thus, the reproductive capacity-camacof the llama is juxtaposed with and differentiated from the sexual promiscuity - hucha - of Chaupi Namca. These passages suggest that the sexuality and fertility linked to reproduction (cama) are related but opposed to non-reproductive, "for pleasure" sexuality (hucha). This helps us to understand why the Catholic clergy chose the term hucha as a translation for "sin," as well as why hucha is often paired in colonial dictionaries with the term cama.

To summarize, in most contexts hucha has the sense of disorderly, destructive, and transgressive behavior, whereas cama is related to forces, objects, or entities involved in classifying, ordering, and/or animating the world in a productive, constructive manner. Hucha and cama appear to stand in a relationship of complementary opposition. That is, cama relates to animation/vivification, orderliness, and duty or obligation, while hucha relates to disorder, destruction, wastefulness, and what might be termed, in a socio-political context, a- or antisocial behavior. I suggest that cama and hucha may be conceived as causally related. That is, the disruption and disorder of hucha are not just opposed to, but actively disturb, the order, creativity, and animation of cama. I suggest further that confession was understood as the means of mediating between the two - that is, of regaining cama after the disruption of hucha.

\section{CONFESSION IN THE PRE-COLUMBIAN ANDES}

It is well documented that Andeans practiced confession before the time of the Spanish conquest, and that they continued to do so after the conquest, relying on native confessional specialists rather than Spanish priests (Harrison 1992: 8; MacCormack 1991: 421). ${ }^{9}$ An early account of Inka confession appears in the 1590 chronicle by the Jesuit priest José de Acosta, which closely parallels the aforementioned account in the Doctrina Christiana by Polo de Ondegardo:

That same father of lies [i.e., the devil] also tried to mimic the sacrament of confession and to make himself honored by his worshipers in a ceremony very similar to the one used by the [Catholic] faithful. In Peru they believed that all adversities and illnesses

\footnotetext{
${ }^{9}$ There has been consternation on the part of Andeanists at the notion that pre-Hispanic Andeans might have held a notion similar to "sin." The topic is not mentioned in D'Altroy's book on Inka civilization (2003). In her analysis of the Inka ceremony of the Capac Hucha, Lydia Fossa Falco first translates this title as Peccado Real, "Royal Sin" (1991: 38-39). However, she goes on to assert, "The concept of $\sin$ is an occidental/Western innovation" (ibid.: 39), implying thereby that the concept did not exist in the pre-Hispanic Andean world. Citing González Holguín's gloss of the term hucha as consulta ("consultation"), Fossa Falco prefers to translate Capac Hucha as Gran Consulta ("Great Consultation"). While I generally agree with her gloss in this particular context, we are still left with the many glosses of hucha as pecado ("sin") in the works of the early Augustinians, Cabello de Balboa, Guaman Poma de Ayala, José de Acosta, Polo Ondegardo, Bernabé Cobo, and other chroniclers (a fact which Fossa Falco does not mention in her short article).
} 
came from sins they had committed and had recourse to sacrifices in order to atone for these; moreover, they also confessed orally in almost all the provinces, and they had both greater and lesser confessors appointed for the purpose and sins reserved for the greater confessor.... They believe that it is a grave offense to hide some sin during confession, and the ichuris, or confessors, discover, either by casting lots or by examining the entrails of some animal, whether they are concealing some sin; and they punish this by striking the person's back many times with a stone until he confesses everything, and then they give him the penance and perform the sacrifice.... The sins that they chiefly confessed were, first of all, killing someone outside of war, also stealing, also taking someone else's wife, also administering herbs or spells to do evil. And carelessness in offering reverence to their huacas, violating festivals, speaking ill of the Inca, and not obeying him were considered very great sins... (Acosta 2002: 304-5).

From what Acosta (as well as Murúa 2001 [1590]: 362-63) understood, confession was important in monitoring and regulating public and private behavior - that is, it was a central discourse of governmentality in the pre-Hispanic Andean world. In addition, confession was instrumental in resolving the tension between hucha (destruction, disorder) and cama (creation, order). Hucha, cama and confession formed a nexus of productive and disruptive practices and states of being-for example, relationships between classification and disorder, and reproductive and illicit sexuality — in Inka religion and political economy.

In this Andean understanding, I do not think we are far away from the nexus of $\sin$ (pecado), confession, and penance that was fundamental to European Catholicism. There is, however, one major difference: whereas Andean peoples understood order and disorder, or creation and destruction, to be intrinsically related, with one essential to and for the other, this was distinct from the Catholic theological position on this matter. In the latter, the ideal and objective of the sacraments and a host of other ministrations directed by the church was the elimination of evil and its source, Satan. I suggest that this conceptual and practical difference underlay much of the misunderstanding that emerged in the Andean colony between Andeans and Spaniards over questions of morality and ethics.

THE HISTORY OF THE KHIPU UNDER A NEW REGIME OF

SIN AND CONFESSION

What became of khipu record keeping after the native accounting tradition, as well as the religious, political, and economic institutions and values that sustained it, fell under the control of the European invaders? The khipu-keepers and their knotted registries became vital sources of information in the postconquest Andean world. During the early colonial period, much of the information contained in these native khipu "texts" was transcribed, translated, and written down, thereby providing the foundation for the burgeoning colonial administrative archives (see Pärssinen and Kiviharju 2004). ${ }^{10}$ Various studies

\footnotetext{
${ }^{10}$ Unfortunately, we do not have an example of a khipu transcription that matches an extant khipu in a museum collection.
} 
have addressed the nature of those administrative accounts and what they tell us about khipu record keeping (e.g., Murra 1982; Urton 2003). Our concern here is with the place of cord keeping in colonial religious institutions and practices.

Early on, the Catholic clergy recognized khipus as potentially useful tools for natives in learning the liturgy and as aides in remembering sins and confessing. For instance, the Jesuit José de Acosta wrote in a 1576 letter that he had been approached by a group of old men, of eighty or ninety years of age, who used khipus in learning the doctrine of Christian teachings (cited in Harrison 2002: 267). Harrison cites another letter written by Acosta in 1577 concerning the mission in Juli, in today's southern Peru, in which men and women sat around the plaza, "passing around some khipu or registers that they have, made of strings and knots, in order to remember what they learn, as we do with writing" (ibid.: 267). One of the sermons published by the Third Provincial Council of Lima in 1583-1584 encouraged natives to make khipus for the confession of sins. Intriguingly, the sermon draws on the language of accounting:

The first thing you have to do, my son, is that you have to think a lot about your sins, and make a khipu out of them: make a khipu like when you are a tambocamayoc [an inn keeper along the royal highway], of what you give out and what they owe you: just like that make a khipu of what you have done against God and against your neighbor, and how many times, a lot or a little. And you can't just say your actions [obras] but also your unclean thoughts [pensamientos malos] ... and after you've thought about it by yourself, and made a khipu based on the Ten Commandments, or as best you can, you must ask God for forgiveness (in Harrison 2002: 268).

Commenting on this passage in his recent study on the use of khipus in colonial Andean parishes, John Charles notes that the admonishment in this sermon drew on Andean methods of storehouse inventory by way of an analogy for recording "the quantity and value of the sinner's credits and debits. This arithmetic function of knotted strings proved especially valuable for a sacramental rite whose integrity rested upon the accurate recall of transgressions and their frequency" (2007: 17; my emphasis). My argument throughout this paper has been that appealing to an accounting-based strategy for promoting the use of khipus may in fact have drawn more directly on pre-conquest uses of khipus than Spaniards at the time understood. Whereas a sermon by a priest playing cleverly on the language of the storehouse inventory as a metaphor for the use of khipus in confession was a smart rhetorical stratagem, I argue that, unbeknownst to that priest, such usage may have been perfectly attuned to a preexisting function of pre-conquest khipus.

Andean men or women, holding knotted bundles of strings representing records of their sins to be recounted in the Catholic sacrament of confession - that is, balancing the books of spiritual and social debits and credits - knew precisely what they were doing. But what they were doing was in fact rather different from what the priest thought they were doing. 
I suspect that in many such encounters, confessants imagined that the need to confess lay in a violation of norms of reciprocity and/or a disturbance of established order, whereas priests imagined (or fervently hoped) that confessants felt a sense of their depravity and a desire for the Christian God's grace and forgiveness. I suspect, moreover, that the khipu - the tangible cords of cotton or camelid fibers - anchored native confessants to a native reality and sensibility more than serving as a medium of transcendence to a new, European reality based on the incorporality of the Christian soul.

Disjunctions such as this reflect the convergence between southern European/Spanish and Andean/Inka record keeping and notions of sin and confession, described in the introduction as history transpiring within a house of mirrors. In the many fraught historical conjunctures that transpired within this particular "fun house," the mirrors were all set slightly askew, so that the actor (the native) and the one overseeing and viewing the performance (the priest) had quite different understandings of what was going on. It must also be noted that not all Spaniards viewed positively the continued use of khipus by the natives, and one provision of the Third Provincial Council (Article 37 ) encouraged priests to destroy khipus that recorded memories of "ancient superstitions" (Harrison 2002: 268-69). Such ambivalence was also articulated poignantly in the writings of a priest, Juan Pérez Bocanegra, who lived near Cusco in the early seventeenth century.

ON THE AMBIGUITIES OF KHIPU USE IN THE COLONY: FROM SUBTERFUGE TO SURVEILLANCE

Some of the most detailed information that has come down to us on khipu use in the colonial Andes appears in testimony from a member of the secular clergy, Juan Pérez Bocanegra, who was priest of the parish of Andahuaylillas, near Cusco, beginning in 1621 (Durston 2007; Harrison 2002). One concern Pérez Bocanegra had with the state of liturgical matters within his parish was the influence of a clandestine native clergy, known as hermanos mayores and hermanas mayores ("older brothers" and "older sisters"), who espoused what he argued were heretical interpretations of the liturgy (Durston 2007: 284; MacCormack 2007: 421). Members of this native priesthood took an active role in encouraging parishioners to make confessional khipus. Pérez Bocanegra was deeply suspicious of the sincerity of the Indians in making confession (Figure 4).

Pérez Bocanegra's text, Ritual formulario, e instrucción de curas. . . (1631), contains a wealth of information on how to observe and monitor native uses of confessional khipus. In Durston's overview, Pérez Bocanegra saw the following problems in his native parishioners' use of khipus for confessional purposes: "The crux of the matter was that Indians who followed the instructions of the hermanos mayores confessed sins that they never committed, confessed actions that were not sins, and omitted the sins they had 


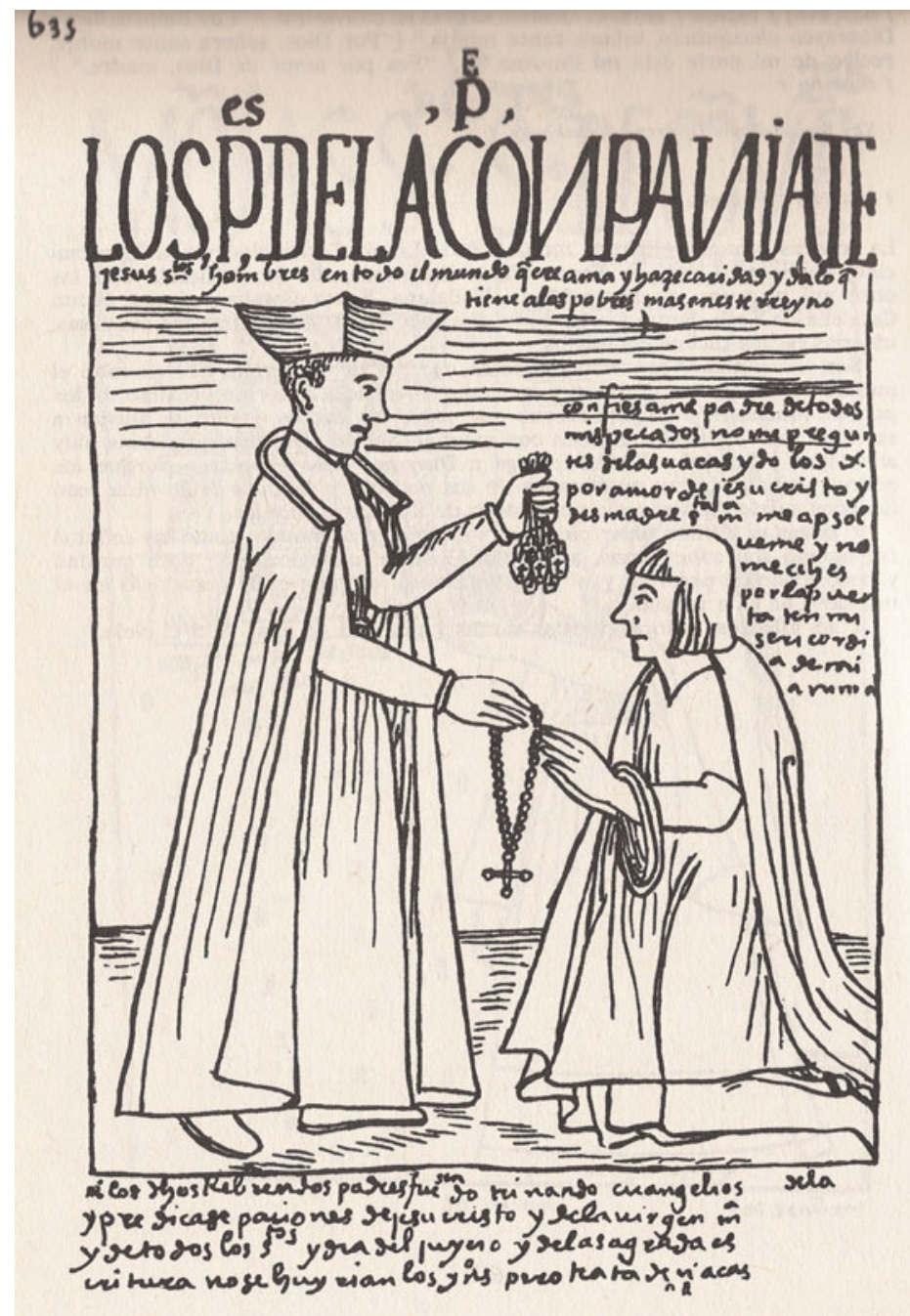

Figure 4 An Andean Indian Giving Confession to a Priest (from Guaman Poma de Ayala, 1980:635).

committed. Worse still, the same quipus were employed on different occasions and by different people. Indians who confessed with quipus were even under the impression that their use somehow sanctified their confessions and left them better prepared to receive communion..." (2007: 287). Pérez Bocanegra's solution to these challenges to confessional verity was to ban them altogether and punish Indians for consulting the native clergy. 
In a recent study of the uses of khipus in colonial parishes, John Charles (2007) analyzes an attempt by colonial civil and ecclesiastical officials to encourage Andean natives to conduct cord-based surveillance of abusive officials. As Charles argues, this particular agenda for khipu use drew on the idea of the political economy of sin, or what he terms the "countable aspect" of sin. This conception was expressed in the metaphor cited earlier in which khipu confessional accounting is represented as a form of storehouse exchange: "You make a khipu of what you give and what you are owed." Charles draws a connection between the mandate to count sins by khipus and the establishment by the Viceroy Francisco de Toledo of officials, known as "notarykhipukamayuq," who were charged with the "moral policing" of communities (ibid.: 28). What emerges in sermons developing these themes is a set of metaphors linking confessional khipus, storehouse exchanges, and the ferreting out and denunciation of immoral, unethical public officials. "The priests' official homily thus accentuated the social obligations of Christian practice and the vital place of accounting one's debts and those of others in upholding the civil order. One can imagine how for Andean neophytes the conceptual domain of individual wrongdoing and absolution would overlap with that of public crime and reparation.... [T] he same cords that penitents used to catalog sins could also record the transgressions committed against them by fellow Andeans, Spanish corregidores [governors], or even parish priests" (ibid.).

The political economy of community policing in the colonial Andes brought out in Charles' study points us back to the place of cord accounting and governmentality in the Inka state. The mestizo chronicler Garcilaso de la Vega saw a connection between khipu accounting for economic purposes in the Inka Empire and the counting by means of khipus of components of the Catholic liturgy (e.g., the Ten Commandments, the works of mercy). As Charles writes, "Garcilaso's testimony highlights the continuity between the numbers that registered the dictates of Christian doctrine and Inca strings that inventoried religious crimes and penalties of restitution" (ibid.: 29). What emerges in this set of reflexive metaphorical constructions are representations and discursive formulations linking individual and public morality, sacramental performance, and transformed (i.e., colonial) khipu accounting practices.

\section{CONCLUSIONS}

In this study, I have described an historical conjuncture in which actors from two distant and radically different parts of the newly formed sixteenth-century global oikoumene, each bearing their respective recording technologies and accounting traditions and maintaining similar beliefs concerning destructive, asocial behaviors and the potentiality of their rectification through confession, came into violent confrontation. In this encounter, the post-Inkaic colonial Andes saw myriad conjunctions-experienced by participants as 
disjunctions_-between superficially similar ideological views and beliefs. These concerned the responsibility individuals in the two societies were thought to bear in the struggle between personal desires and intentions motivating action in the world, on one hand, and the effects of such actions on social stability and order, especially when they were interpreted by the powers-that-be as counter-hegemonic, or un- (or anti-) orthodox, on the other.

During the two or three centuries before these two societies came into contact, each had developed complicated ideas about "sin," about the deleterious effects of such actions on and in society, and about the necessity of confession for resolving problems caused by "sinful" behavior. In their postconquest, colonial confrontations, the Spanish clergy and their allies, who were in a politically dominant position vis-à-vis Andean peoples, utterly condemned and sought to eliminate completely Andean beliefs and practices. This occurred in many different settings, one of the principal ones being confession, when natives holding bundles of knotted cords confronted priests and attempted to account for moral and ethical debits and credits in the conduct of their lives.

In sum, I argue that encounters between confessors and confessants, like those described above, were a vital and integral part of pre-conquest Andean accounting practices; second, that there was a significant disjunction between what natives and the Catholic priests imagined was transpiring in such encounters in the colonial setting; and finally, that such episodes as these, centering around the political economy of balancing debits and credits in the spheres of social, political, and religious morality, united Andeans with people an ocean away in the transcultural technological and intellectual traditions of their respective arts of bookkeeping and accounting.

\section{REFERENCES}

Acosta, J. d. 2002. Natural and Moral History of the Indies. Durham and London: Duke University Press.

Aho, J. 2005. Confession and Bookkeeping: The Religious, Moral, and Rhetorical Roots of Modern Accounting. Albany: State University of New York Press.

Ascher, M. and R. Ascher. 1997. Mathematics of the Incas: Code of the Quipus. New York: Dover.

Bossy, J. 1975. The Social History of Confession in the Age of the Reformation. Transactions of the Royal Historical Society. Fifth Series, 25: 21-38.

Brown, R. G. and K. S. Johnston. 1984 [1963]. Paciolo on Accounting. New York and London: Garland Publishing Co.

Buckmaster, D. 1974. The Incan Quipu and the Jacobsen Hypothesis. Journal of Accounting Research 12, 1: 178-81.

Burkhart, L. M. 1989. The Slippery Earth: Nahua-Christian Moral Dialogue in Sixteenth-Century Mexico. Tucson: The University of Arizona Press.

Cabello de Balboa, M. 1951. Miscelánea antártica. Lima: Instituto de Etnología, Universidad Nacional Mayor de San Marcos. 
Carruthers, B. G. and W. N. Espeland. 1991. Accounting for Rationality: Double-Entry Bookkeeping and the Rhetoric of Economic Rationality. The Journal of American Sociology 97, 1: 31-69.

Charles, J. 2007. Unreliable Confessions: Khipus in the Colonial Parish. The Americas 64, 1: 11-33.

Cieza de León, P. de 1967 [1553]. El Señorio de los Incas. Lima: Instituto de Estudios Peruanos.

Cobo, B. 1990. Inca Religion and Customs. R. Hamilton, trans. Austin: University of Texas Press.

D'Altroy, T. 2003. The Incas. London: Blackwell Publishers.

Doctrina Christiana y Catecismo para Instrucción de Indios. 1985 [1584-1585]. Corpus Hispanorum de Pace XXVI-2. Madrid: Consejo Superior de Investigaciones Cientificas.

Donoso Anes, R. 1994. The Double-Entry Bookkeeping Method Applied in Spain to Account for Transactions Related to the Minting Process of Gold and Silver in the Sixteenth Century. The Accounting Historians Journal 21, 1: 97-116.

Durston, A. 2007. Pastoral Quechua: The History of Christian Translation in Colonial Peru, 1550-1650. South Bend, Ind.: University of Notre Dame Press.

Elliott, J. H. 1989. Spain and Its World, 1500-1700. New Haven and London: Yale University Press.

Epstein, S. A. 2001. Genoa and the Genoese, 958-1528. Chapel Hill: University of North Carolina Press.

Estenssoro Fuchs, J. C. 2003. Del paganismo a la santidad: La incorporación de los indios del Peru al catolicismo, 1532-1750. Lima: Instituto Francés de Estudios Andinos and Pontificia Universidad Católica del Perú.

Forrester, D. A. R. 1968. The Incan Contribution to Double-Entry Accounting. Journal of Accounting Research 6, 2: 283.

Fossa Falco, L. 1991. Leyendo hoy a Cieza de Leon: De la Capacocha a la Capac Hucha. Boletín de Lima 73: 33-41.

Foucault, M. 2000 [1978]. Governmentality. In J. D. Faubion, ed., Power: Essential Works of Foucault, 1954-1984. Vol. 3. Penguin Books, London, 201-22.

Garcilaso de la Vega, E. I. 1966. Royal Commentaries of the Incas. H. V. Livermore, trans. 2 vols. Austin: University of Texas Press.

Gónzalez Holguín, D. de 1952 [1608]. Vocabulario de la lengua general de todo el Perú llamada lengua Qquichua o del Inca. Lima: Universidad Nacional Mayor de San Marcos.

Guaman Poma de Ayala, F. 1980. El primer nueva corónica y buen gobierno. John V. Murra and Rolena Adorno, eds, J. L. Urioste, trans. 3 vols. Mexico City: Siglo Veintiuno.

Harrison, R. 1992. 'True' Confessions: Quechua and Spanish Cultural Encounters in the Viceroyalty of Peru. University of Maryland at College Park: Latin American Studies Center Series 5.

. 2002. Pérez Bocanegra's Ritual Formulario: Khipu Knots and Confession. In J. Quilter and G. Urton, eds., Narrative Threads. Austin: University of Texas Press, 266-90.

Horswell, M. J. 2005. Decolonizing the Sodomite: Queer Tropes of Sexuality in Colonial Andean Culture. Austin: University of Texas Press.

Jacobsen, L. E. 1964. The Ancient Inca Empire of Peru and the Double Entry Accounting Concept. Journal of Accounting Research 2, 2: 221-28.

Julien, C. 1988. How Inca Decimal Administration Worked. Ethnohistory 35, 3: $257-79$.

LeVine, T. Y. 1987. Inka Labor Service at the Regional Level: The Functional Reality. Ethnohistory 34, 1: 14-46. 
Little, L. 1978. Religious Poverty and the Profit Economy in Medieval Europe. London: P. Elek.

Locke, L. L. 1923. The Ancient Quipu or Peruvian Knot Record. New York: American Museum of Natural History.

Lopez, R. S. 1987. The Commercial Revolution of the Middle Ages, 950-1350. Cambridge: Cambridge University Press.

MacCormack, S. 1991. Religion in the Andes: Vision and Imagination in Early Colonial Peru. Princeton: Princeton University Press.

. 2007. On the Wings of Time: Rome, The Incas, Spain, and Peru. Princeton and Oxford: Princeton University Press.

Mannheim, B. 1991. The Language of the Inka since the European Invasion. Austin: University of Texas Press.

Mariéjol, J. H. 1961. The Spain of Ferdinand and Isabella. New Brunswick, N.J.: Rutgers University Press.

Murra, J. V. 1982. The Mit'a Obligations of Ethnic Groups to the Inka State. In G. A. Collier, R. Renato, and J. D. Wirth, eds., The Inca and Aztec States, 1400-1800: Anthropology and History. New York: Academic Press, 237-62.

Murray, A. 1993. Confession before 1215. Transactions of the Royal Historical Society. 6th series, 3: $51-81$.

Murúa, F. M. de 2001. Historia General del Perú. Madrid: Dastin Historia.

Pärssinen, M. 1992. Tawantinsuyu: The Inca State and Its Political Organization. Studia Historica 43. Helsinki: Societas Historica Finlandiae.

Pärssinen, M. and J. Kiviharju, eds. 2004. Textos Andinos: Corpus de Textos khipu incaicos y coloniales. Madrid: I. Instituto Iberoamericano de Finlandia and Universidad Complutense de Madrid.

Peragallo, E. 1938. Origin and Evolution of Double Entry Bookkeeping: A Study of Italian Practice from the Fourteenth Century. New York: American Institute Publishing Company.

Pérez Bocanegra, J. 1631. Ritual formulario e instrución de curas. Lima: Geronymo de Contreras.

Phelan, J. L. 1960. Authority and Flexibility in the Spanish Imperial Bureaucracy. Administrative Science Quarterly 5, 1: 47-65.

Phillips, C. R. and W. D. Phillips, Jr. 1997. Spain's Golden Fleece: Wool Production and the Wool Trade from the Middle Ages to the Nineteenth Century. Baltimore and London: Johns Hopkins University Press.

Pike, R. 1966. Enterprise and Adventure: The Genoese in Seville and the Opening of the New World. Ithaca: Cornell University Press.

Pizarro, H. 1920. A los Señores Oydores de la Audiencia Real de Su Magestad. In, H. H. Urteaga, ed., Informaciones sobre el antiguo Perú. Colección de Libros y Documentos References a la Historia del Perú. Vol. 3 (2d series). Lima: Sanmartí y Ca., $167-80$.

Platt, T. 1987. Entre Ch'axwa y Muxsa: Para una historia del pensamiento político aymara. In T. Bouysse-Cassagne, et al., eds., Tres reflexiones sobre el pensamiento andino. LaPaz: HISBOL, 61-132.

Polo de Ondegardo, J. 1916. Informaciones acerca de la Religión y Gobierno de los Incas. Colección de Libros y Documentos Referentes a la Historia del Perú 4. Lima: Sanmartí y Calif.

Presta, A. M. and C. Julien. 2008. Polo Ondegardo (ca. 1520-1575). In J. Pillsbury, ed., Guide to Documentary Sources for Andean Studies, 1530-1900. Vol. 3. Norman: University of Oklahoma Press, 529-35. 
Reitzer, L. 1960. Some Observations on Castilian Commerce and Finance in the Sixteenth Century. The Journal of Modern History 32, 3: 213-23.

Salomon, F. 2004. The Cord Keepers: Khipus and Cultural Life in a Peruvian Village. Durham and London: Duke University Press.

Salomon, F. and J. L. Urioste. 1991. The Huarochiri Manuscript: A Testament of Ancient and Colonial Andean Religion. Austin: University of Texas Press.

San Pedro, F. J. de 1992. La persecución del demonio: Crónica de los primeros Agustinos en el Norte del Perú (1560). Transcribed by E. E. Deeds. Málaga: Editorial Algazara.

Sombart, W. 1967. The Quintessence of Capitalism. M. Epstein, trans. New York: Howard Fertig.

Stewart, P. 1969. The Soldier, the Bureaucrat, and Fiscal Records in the Army of Ferdinand and Isabella. The Hispanic American Historical Review 49, 2: 281-92.

Swetz, F. J. 1989. Capitalism and Arithmetic: The New Math of the 15th Century. Chicago: University of Chicago Press.

Taylor, G. 2000. Camac, camay y camasca y otros ensayos sobre Huarochiri y Yauyos. Cuzco: Centro 'Bartolomé de las Casas.'

Tentler, T. N. 1977. Sin and Confession on the Eve of the Reformation. Princeton: Princeton University Press.

Thompson, G. 1991. Is Accounting Rhetorical? Methodology, Luca Pacioli and Printing. Accounting, Organizations and Society 16, 5/6: 573-99.

Urton, G. 1994. A New Twist in an Old Yarn: Variation in Knot Directionality in the Inka Khipus. Baessler-Archiv Neue Folge 42: 271-305.

1998. From Knots to Narratives: Reconstructing the Art of Historical RecordKeeping in the Andes from Spanish Transcriptions of Inka Khipus. Ethnohistory 45, 3: 409-38.

2001. A Calendrical and Demographic Tomb Text from Northern Peru. Latin American Antiquity 12, 2: 127-47.

2003. Signs of the Inka Khipu: Binary Coding in the Andean Knotted-String Records. Austin: University of Texas Press.

2005. Khipu Archives: Duplicate Accounts and Identity Labels in the Inka Knotted String Records. Latin American Antiquity 16, 2: 147-67.

- 2006. Censos registrados en cordeles con 'Amarres': Padrones poblacionales pre-Hispánicos y coloniales tempranos en los Khipus Inka. Revista Andina 42: $153-96$.

Urton, G. and C. J. Brezine. 2005. Khipu Accounting in Ancient Peru. Science 309: 1065-67.

Weber, M. 1948 [1930]. The Protestant Ethic and the Spirit of Capitalism. T. Parsons, trans. London: George Allen and Unwin Ltd.

Yamey, B. S. 1964. Accounting and the Rise of Capitalism: Further Notes on a Theme by Sombart. Journal of Accounting Research 2, 2: 117-36. 